\title{
Evaluation of the Effect of Phytol on the Formation of PAHs in Cigarette Smoke*
}

\author{
by \\ Serban C. Moldoveanu, William M. Coleman III, Niraj. P. Kulshreshtha \\ R.J. Reynolds Tobacco Co., 950 Reynolds Blvd., Winston-Salem, NC 27105 USA
}

\section{SUMMARY}

Phytol or (2E,7R,11R)-3,7,11,15-tetramethyl-2-hexadecen$1-$ ol $(M W=296.53$ a.u. $)$, is naturally present in tobacco at levels around $100-150 \mu \mathrm{g} / \mathrm{g}$ dry leaf, where it is bound in the form of an ester to a porphyrine type group (known as chlorin) with several substituents and chelated to $\mathrm{Mg}^{2+}$ ion, to form chlorophyll. This study evaluated the formation of PAHs when several levels of phytol up to ten times higher than typical phytol level were added on 3R4F cigarettes. The cigarettes were smoked under two different smoking conditions. One regimen (indicated as 35/60) used $35 \mathrm{~mL}$ puff volume, $2 \mathrm{~s}$ puff duration, each puff taken every $60 \mathrm{~s}$, and in the other used $60 \mathrm{~mL}$ puff volume, $2 \mathrm{~s}$ puff duration, each puff taken every $30 \mathrm{~s}$ (indicated as 60/30). The increase in the PAHs level upon phytol addition was not significant. A statistical evaluation of the dependence of total PAHs and the added level of phytol showed that the hypothesis of a zero slope for the dependence line phytol/total PAHs cannot be rejected (with a $p=0.101$ for $35 / 60$ smoking and $p=0.626$ for $60 / 30$ smoking). Still, for $35 / 60$ smoking conditions, an increase of about $14 \%$ in total levels of PAHs was noticed when the added phytol level was $1.5 \mathrm{mg}$ phytol per cigarette. However, this PAHs increased level was not necessarily determined by the phytol addition, and can be caused by random procedural/analytical errors (as indicated by the statistical analysis) or by the modification of cigarettes during phytol addition. Also, the observed level is much lower than the expected $100 \%$ increase in the PAHs level, based on literature prediction. Intensive smoking did not show an increase in PAHs level at all. Flash pyrolysis of free phytol and of chlorophyll $a$ provided results that indicated that phytol bound in chlorophyll is not likely to generate different PAHs level compared to free phytol. Thus, phytol has been shown not to be a significant contributor/precursor to the PAHs formation in cigarette smoke. [Beitr. Tabakforsch. Int. 24 (2010) 10-23]

\section{ZUSAMMENFASSUNG}

Phytol oder (2E,7R,11R)-3,7,11,15-tetramethyl-2-hexadecen-1-ol ( $M W=296.53$ a.u.) kommt natürlicherweise in einer Menge zwischen 100-150 mg/g Trockenblätter vor, wo es in Form eines Esters an eine Porphyringruppe (bekannt als Chlorin) gebunden vorliegt. Es bildet mit verschiedenen Substituenten und an $\mathrm{Mg}^{2+}$ cheliert das Chlorophyll. Diese Arbeit untersucht den Einfluss unterschiedlicher zugesetzter Phytolmengen zu 3R4F Zigaretten (bis zu 10mal höhere Mengen als normale Phytolmengen) auf die Bildung von polyzyklischen aromatischen Kohlenwasserstoffen (PAK).

Die Zigaretten wurden nach zwei verschiedenen Verfahren abgeraucht. Bei dem einen Abrauchverfahren (im weiteren als 35/60 bezeichnet) wurde alle $60 \mathrm{~s}$ ein Zug mit $35 \mathrm{ml}$ Zugvolumen und $2 \mathrm{~s}$ Zugdauer genommen, während bei dem anderen Abrauchverfahren alle $30 \mathrm{~s}$ ein Zug mit $60 \mathrm{ml}$ Zugvolumen und 2 s Zugdauer (im weiteren als 60/30 bezeichnet) genommen wurde. Durch die Zugabe von Phytol kam es zu keinem signifikanten Anstieg der Menge an PAK. Eine statistische Auswertung der Abhängigkeit der Gesamtmenge an PAK und dem zugegebenen Phytol zeigte, dass die Hypothese eines Nullanstieges für die Abhängigkeitslinie Phytol/Gesamt PAK nicht ausgeschlossen werden kann (mit einem $p=0.101$ für das 35/60und $p=0.626$ für das $60 / 30$-Verfahren). Weiterhin konnte ein Anstieg von 14\% der Gesamtmenge an PAK bei der Zugabe von $1.5 \mathrm{mg}$ Phytol pro Zigarette bei der Bedingung 35/60 beobachtet werden. Allerdings muss dieser Anstieg der Menge an PAK nicht notwendigerweise durch die Phytolzugabe bedingt sein, sondern kann durch zufällige verfahrens- bzw. analytisch-bedingte Fehler (wie die statistische Auswertung zeigt) oder durch die Modifikation der Zigaretten während der Phytolzugabe verursacht worden sein. Außerdem war die beobachtete Menge der PAK sehr viel geringer als der 100\%ige Anstieg, der in der Literatur prognostiziert wird. Ergebnisse einer FlashPyrolysestudie von freiem Phytol und von Chlorophyll $a$ weisen darauf hin, dass Phytol, wenn es an Chlorophyll 
gebunden vorliegt, mit einer geringeren Wahrscheinlichkeit verschiedene PAK bildet als freies Phytol. Demzufolge konnte gezeigt werden, dass Phytol kein charakteristischer Vorläufer für PAK im Zigarettenrauch ist. [Beitr. Tabakforsch. Int. 24 (2010) 10-23]

\section{RESUME}

Le phytol ou (2E,7R,11R)-3,7,11,15-tétraméthyl-2-héxadécène-1-ol ( $\mathrm{pm}=296,53$ unité arbitraire) est naturellement présent dans le tabac à des niveaux d'environ 100 à $150 \mathrm{mg} / \mathrm{g}$ dans les feuilles sèches où il est lié, sous forme estérifiée, à un groupe de type porphyrine (connu sous le nom de chlorin) avec plusieurs substituant et chélaté à un ion $\mathrm{Mg}^{2+}$ pour former de la chlorophylle. Cette étude a évalué la formation d'HAP (hydrocarbures aromatiques polycycliques) quand plusieurs niveaux de phytol jusqu'à dix fois supérieurs au niveau de phytol typique ont été ajoutés à des cigarettes 3R4F. Les cigarettes ont été fumées dans deux conditions de fumage différentes. Une dose (indiquée comme 35/60) utilisait $35 \mathrm{ml} \mathrm{du}$ volume de la bouffée, lors d'une bouffée de $2 \mathrm{~s}$, chaque bouffée étant aspirée toutes les $60 \mathrm{~s}$, et l'autre utilisait $60 \mathrm{ml}$ du volume de la bouffée, lors d'une bouffée de $2 \mathrm{~s}$, chaque bouffée étant aspirée toutes les $30 \mathrm{~s}$ (indiquée comme 60/30). L'augmentation du niveau d'HAP après l'ajout de phytol n'a pas été significative. Une évaluation statistique de la dépendance des HAP totaux et du niveau ajouté de phytol ont montré que l'hypothèse d'une boucle zéro de la ligne de dépendance phytol/HAP totaux ne peut être exclue (avec $p=0,101$ pour un fumage de 35/60 et $p=0,626$ pour un fumage de $60 / 30$ ). Par ailleurs, pour des conditions de fumage de $35 / 60$, une augmentation de près de $14 \%$ des niveaux totaux d'HAP a été constatée lorsque le niveau de phytol ajouté était de 1,5 mg de phytol par cigarette. Toutefois, ce niveau accru d'HAP n'a pas forcément été déterminé par l'ajout de phytol et peut être causé par des erreurs aléatoires de procédure / d'analyse (comme indiqué par l'analyse statistique) ou par la modification des cigarettes pendant l'ajout de phytol. Le niveau constaté est également nettement inférieur aux $100 \%$ d'augmentation attendus dans le niveau des HAP sur la base des prévisions mentionnées dans la littérature. Un fumage intense n'a révélé aucune augmentation du niveau d'HAP. Une pyrolyse flash de phytol libre et de chlorophylle $a$ a fourni des résultats indiquant qu'il est peu probable que le phytol lié à la chlorophylle génère des niveaux d'HAP différents comparés à ceux du phytol libre. Ainsi, il a été démontré que le phytol n'est pas un contributeur/précurseur significatif de la formation d'HAP dans la fumée de cigarette. [Beitr. Tabakforsch. Int. 24 (2010) 10-23]

\section{INTRODUCTION}

Phytol or (2E,7R,11R)-3,7,11,15-tetramethyl-2-hexadecen$1-o l(M W=296.53$ a.u. $)$, is present in tobacco at levels around $100-150 \mu \mathrm{g} / \mathrm{g}$ dry leaf. The compound is bound in the form of an ester to a porphyrine type group (known as chlorin) with several substituents and chelated to $\mathrm{Mg}^{2+}$ ion, to form chlorophyll. Pyrolysis of phytol has been studied with various purposes such as the elucidation of the role of chlorophyll in the formation of petroleum and of oil shale kerogens $(1,2)$, understanding of the degradation of lignocellulosic biomass containing chlorophyll (3), understanding of the formation in time of humic substances $(4,5)$, as well as specifically for the potential formation of polycyclic aromatic hydrocarbon (PAHs) (6-8). When pyrolyzed in a quartz tube at $860 \pm 5{ }^{\circ} \mathrm{C}$ in a flow of nitrogen $(30 \mathrm{~mL} / \mathrm{min})$ phytol was reported to generate benzo $[a]$ pyrene at a level of about $3.9 \mathrm{mg} / \mathrm{g}$ from the initial phytol (8). In a flash pyrolysis experiment performed at $900{ }^{\circ} \mathrm{C}$ for $10 \mathrm{~s}$ the pyrolysis products were found more similar to those of a long chain hydrocarbon than those of a typical alcohol (6). This is common for a large molecule where the functional group is only a small part of a much larger structure. The formation of (2E)-3,7,11,15-tetramethylhexadec-2-enal does take place as expected from an alcohol, but the compound is present in the pyrolyzate at only $0.2 \%$ (mol) from the total pyrolyzate composition. The reaction is shown below:

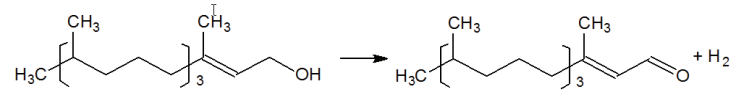

Elimination of water is unlikely without rearrangement of the double bond from the 2-position. In the case of phytol, most pyrolysis products are various fragments of the phytol molecule from along the hydrocarbon chain. Since long chain hydrocarbon pyrolysis does not generate PAHs with high yield by pyrolysis, preliminary results on phytol flash pyrolysis are in disagreement with the reported results from the study showing a level of about $3.9 \mathrm{mg}$ of benzo[a]pyrene per $1 \mathrm{~g}$ of pyrolyzed phytol (8). The main purpose of the present study is to determine the potential increase in the level of PAHs when phytol is added at several levels on cigarettes.

Since phytol is present in tobacco mainly as an ester bound to chlorophyll, the contribution of phytol moiety to the composition of the total pyrolyzate of chlorophyll was another aspect of interest. To clarify this subject, the pyrolyzates of phytol and of chlorophyll performed under similar conditions were compared and this report describes the findings.

\section{EXPERIMENTAL}

\section{Cigarette treatment}

The first part of this study was focused on the evaluation of phytol potential to increase the level of PAHs in cigarette smoke. The cigarettes used for the study were $3 \mathrm{R} 4 \mathrm{~F}$ Kentucky reference cigarettes. Several levels of phytol were added to the cigarettes. For this purpose, phytol (Sigma-Aldrich, Milwaukee, WI 53201, USA) was used to make a $10 \%(\mathrm{w} / \mathrm{v})$ solution in ethanol. Then $1 \mu \mathrm{L}, 5 \mu \mathrm{L}$, $10 \mu \mathrm{L}$ and $15 \mu \mathrm{L}$, respectively, of this solution were 
Table 1. Level of added phytol on 3R4F cigarettes

\begin{tabular}{lc}
\hline Level & $\mu \mathrm{g} / \mathrm{cig}$ \\
\hline Level 0 & initial \\
Level 1 & initial $+100 \mu \mathrm{g} / \mathrm{cig}$ \\
Level 5 & initial $+500 \mu \mathrm{g} / \mathrm{cig}$ \\
Level 10 & initial $+1000 \mu \mathrm{g} / \mathrm{cig}$ \\
Level 15 & initial $+1500 \mu \mathrm{g} / \mathrm{cig}$ \\
\hline
\end{tabular}

Table 2. Deuterated I.S. solution (Concentration in isopropanol, $\mu \mathrm{g} / \mathrm{mL}$ )

\begin{tabular}{rlrr}
\hline No & Compound & MW & Sol I.S. \\
\hline 1 & Naphthalene-d8 & 136 & 29.72 \\
2 & 2-Methylnaphthalene-d10 & 152 & 29.92 \\
3 & Acenaphthene-d10 & 164 & 8.00 \\
4 & Fluorene-d10 & 176 & 30.40 \\
5 & Phenanthrene-d10 & 188 & 15.68 \\
6 & Anthracene-d10 & 188 & 10.44 \\
7 & Pyrene-d10 & 212 & 7.68 \\
8 & Chrysene-d12 & 240 & 2.84 \\
9 & Benzo[a]pyrene-d12 & 264 & 1.60 \\
10 & Indeno[1,2,3-cd]pyrene-d12 & 288 & 0.84 \\
11 & Dibenz[a,h]anthracene-d14 & 292 & 0.40 \\
12 & Benzo[ghi]perylene-d12 & 288 & 0.48 \\
\hline
\end{tabular}

Table 3. Conditions for sample cleanup on SPE

\begin{tabular}{l|l|l|r|c}
\hline No & Step & Source & $\begin{array}{c}\text { Volume } \\
\mathrm{mL}\end{array}$ & $\begin{array}{c}\text { Approx. rate } \\
\mathrm{mL} / \mathrm{min}\end{array}$ \\
\hline 1 & Condition & Methanol & 2.0 & 10 \\
2 & Condition & Water/methanol 65/35 & 2.0 & 10 \\
3 & Load & Sample & 12.0 & 5 \\
4 & Rinse & Water & 1.6 & 10 \\
5 & Rinse & Water & 1.6 & 10 \\
6 & Rinse & Water & 1.6 & 10 \\
7 & Rinse & Water/methanol 65/35 & 1.6 & 10 \\
8 & Dry & Vacuum for 30 min & & \\
9 & Collect & Cyclohexane & 0.8 & 5 \\
\hline
\end{tabular}

injected manually in $3 \mathrm{R} 4 \mathrm{~F}$ cigarettes. The cigarettes were allowed to equilibrate for two weeks. After two weeks it was noticed that some cigarettes developed some spotting. The cigarettes with no spots and also those with spots smaller than 2-3 $\mathrm{mm}$ in diameter were used in the study. The added levels of phytol on the 3R4F cigarettes are shown in Table 1.

The cigarettes were smoked on a Borgwaldt rotary machine RM20/CSR (Schnackenburgallee 15, D-22525 Hamburg, Germany) using two smoking regimens. One regimen (indicated as 35/60) used $35 \mathrm{~mL}$ puff volume, $2 \mathrm{~s}$ puff duration, each puff taken every $60 \mathrm{~s}(9)$, and the other used $60 \mathrm{~mL}$ puff volume, $2 \mathrm{~s}$ puff duration, each puff taken every $30 \mathrm{~s}$ (indicated as 60/30). The total particulate matter (TPM) from 5 cigarettes was collected on $44 \mathrm{~mm}$ Cambridge pads. For control, 2R4F cigarettes (with no added phytol) were also smoked in the same two conditions.
Table 4. GC/MS operating parameters

\begin{tabular}{lc}
\hline Parameter & Description \\
\hline GC column & Rxi-5Sil MS ${ }^{\text {a }}$ \\
Column dimensions & $30 \mathrm{~m}, 0.25 \mathrm{~mm}$ i.d. \\
Film thickness & $0.25 \mu \mathrm{m}$ \\
Initial oven temperature & $35^{\circ} \mathrm{C}$ \\
Initial time & $2.0 \mathrm{~min}$ \\
Oven ramp rate & $20^{\circ} \mathrm{C} / \mathrm{mm}$ \\
Oven final first ramp & $100^{\circ} \mathrm{C}$ \\
Final time first ramp & $5.75 \mathrm{~min}$ \\
Oven ramp rate & $25^{\circ} \mathrm{C} / \mathrm{mm}$ \\
Oven final first ramp & $150^{\circ} \mathrm{C}$ \\
Final time first ramp & $0 \mathrm{~min}$ \\
Oven ramp rate & $4{ }^{\circ} \mathrm{C} / \mathrm{mm}$ \\
Oven final temperature & $320^{\circ} \mathrm{C}$ \\
Final time & $15.5 \mathrm{~min}$ \\
Total run time & $71.0 \mathrm{~min}$ \\
Carrier gas & $\mathrm{Helium}$ \\
Flow mode & Constant pressure \\
Pressure & $21.00 \mathrm{psi}$ \\
Nominal initial flow & $2.8 \mathrm{~mL} / \mathrm{min}$ \\
GC outlet & $\mathrm{MSD}$ \\
MSD transfer line & $280^{\circ} \mathrm{C}$ \\
lon source temperature & $230^{\circ} \mathrm{C}$ \\
Quadrupole temp. & $150^{\circ} \mathrm{C}$ \\
MSD EM offset & $250 \mathrm{~V}$ \\
MSD solvent delay & $12.0 \mathrm{~min}$ \\
MSD acquisition mode & $\mathrm{SIM}$ \\
\hline &
\end{tabular}

${ }^{a}$ The Rxi-5Sil MS column was purchased from Restek, Bellefonte, PA 16823, USA.

\section{Smoke sample analysis}

A number of PAHs were analyzed in the smoke collected from the cigarettes. The analysis was done using a modification of a procedure previously described in the literature (10). A brief description of the used procedure follows. After smoking, each pad was put in an extraction vial (with the volume of about $100 \mathrm{~mL}$ ). To each vial there were added $100 \mu \mathrm{L}$ of a solution of deuterated internal standards (CDN Isotopes, Pointe-Claire, Quebec, Canada H9R 1H1, and Supelco, Bellefonte, PA 16823-0048 USA). The list and the concentrations of the deuterated PAHs used as internal standard are given in Table 2.

After this step the pads from cigarettes smoked using 35/60 conditions were extracted with $10 \mathrm{~mL}$ methanol for $30 \mathrm{~min}$ on a mechanical shaker. The cigarettes smoked using 60/30 conditions were extracted with $20 \mathrm{~mL}$ methanol for $30 \mathrm{~min}$ on the shaker. From the methanol solution, $5 \mathrm{~mL}$ were transferred in a test tube. In the test tubes, to the $5 \mathrm{~mL}$ methanol $7 \mathrm{~mL}$ of distilled water was added. A slight turbidity was typically seen in the solution. The test tubes with $12 \mathrm{~mL}$ solution were used for loading the sample into SPE cartridges. The cartridges were CECYH1 (cyclohexyl endcapped) $500 \mathrm{mg}, 3 \mathrm{~mL}$ volume (UCT, Bartram Rd., Bristol, PA 19007). The cleanup process was performed manually using the same procedure as previously recommended for a Rapid Trace automatic SPE system (Zymark/Caliper Life Sciences, Hopkinton, MA 01748). The parameters for the SPE procedure are listed in Table 3. 
Table 5. PTV operating parameters

\begin{tabular}{lc}
\hline Parameter & Description \\
\hline Inlet temperature & $40^{\circ} \mathrm{C}$ \\
Equilib. time & $0.5 \mathrm{~min}$ \\
Initial time & $0.6 \mathrm{~min}$ \\
Injection volume & $3.0 \mu \mathrm{L}$ \\
Air volume below & $1.0 \mu \mathrm{L}$ \\
Eject speed & $10.0 \mu \mathrm{L} / \mathrm{s}$ \\
Rate 1 & $10^{\circ} \mathrm{C} / \mathrm{s}$ \\
End temperature & $320^{\circ} \mathrm{C}$ \\
Hold time & $10.0 \mathrm{~min}$ \\
Rate 2 & $10^{\circ} \mathrm{C} / \mathrm{s}$ \\
End temperature 2 & $375^{\circ} \mathrm{C}$ \\
Hold time 2 & $60.0 \mathrm{~min}$ \\
\hline
\end{tabular}

Table 6. Retention times and ion monitored for quantitation in SIM acquisition for the PAHs analyzed in this study

\begin{tabular}{|c|c|c|c|c|}
\hline No & Compound & Ret. time & SIM Ion & Remark \\
\hline 1 & Naphthalene-d8 & 9.11 & 136 & I.S. \\
\hline 2 & Naphthalene & 9.19 & 128 & \\
\hline 3 & 2-Methylnaphthalene-d10 & 12.25 & 152 & I.S. \\
\hline 4 & 2-Methylnaphthalene & 12.33 & 142 & \\
\hline 5 & 1-Methylnaphthalene & 12.60 & 142 & \\
\hline 6 & Acenaphthylene & 14.59 & 152 & \\
\hline 7 & Acenaphthene-d10 & 15.02 & 164 & I.S. \\
\hline 8 & Acenaphthene & 15.10 & 154 & \\
\hline 9 & Fluorene-d10 & 16.64 & 176 & I.S. \\
\hline 10 & Fluorene & 16.74 & 166 & \\
\hline 11 & Phenanthrene-d10 & 20.33 & 188 & I.S. \\
\hline 12 & Phenanthrene & 20.43 & 178 & \\
\hline 13 & Anthracene-d10 & 20.57 & 188 & I.S. \\
\hline 14 & Anthracene & 20.65 & 178 & \\
\hline 15 & Fluoranthene & 26.33 & 202 & \\
\hline 16 & Pyrene-d10 & 27.37 & 212 & I.S. \\
\hline 17 & Pyrene & 27.46 & 202 & \\
\hline 18 & Benz[a]anthracene & 34.47 & 228 & \\
\hline 19 & Chrysene-d12 & 34.51 & 240 & I.S. \\
\hline 20 & Chrysene & 34.66 & 228 & \\
\hline 21 & Benzo[b]fluoranthene & 40.43 & 252 & \\
\hline 22 & Benzo[k]fluoranthene & 40.57 & 252 & \\
\hline 23 & Benzo[a]pyrene-d12 & 41.89 & 264 & I.S. \\
\hline 24 & Benzo[a]pyrene & 42.01 & 252 & \\
\hline 25 & Indeno[1,2,3-cd]pyrene-d12 & 47.20 & 288 & I.S. \\
\hline 26 & Indeno[1,2,3-cd]pyrene & 47.29 & 276 & \\
\hline 27 & Dibenz[a,h]anthracene-d14 & 47.40 & 292 & I.S. \\
\hline 28 & Dibenz[a, $h]$ anthracene & 47.53 & 278 & \\
\hline 28 & Benzo[ghi]perylene-d12 & 48.24 & 288 & I.S. \\
\hline 29 & Benzo[ghi]perylene & 48.35 & 276 & \\
\hline
\end{tabular}

The final eluates are transferred into sample vials with $100 \mu \mathrm{L}$ small volume inserts in order to perform the GC/MS analysis.

The analysis of PAHs was performed on a $6890 \mathrm{GC} / 5973$ MS instrument (Agilent, Wilmington, Delaware 19808), having a Gerstel (Gerstel, GmbH \& Co.KG, D-45473 Mülheim an der Ruhr, Germany) programmed temperature vaporizer (PTV) injection port. The parameters for the GC instrument are given in Table 4 and for the PTV injector in Table 5. Using the parameters indicated in Tables 4 and 5,
Table 7. The values for the response factors $F$ used for the quantitation

\begin{tabular}{ll}
\hline Factor used for quantitation & Value \\
\hline Naphthalene/naphthalene-d8 & 1.033337 \\
2-Methylnaphthalene/2-methylnaphthalene-d10 & 1.006364 \\
1-Methylnaphthalene/2-methylnaphthalene-d10 & 1.086625 \\
Acenaphthylene/acenaphthene-d10 & 0.917304 \\
Acenaphthene/acenaphthene-d10 & 1.09472 \\
Fluorene/fluorene-d10 & 0.897411 \\
Phenanthrene/phenanthrene-d10 & 1.145231 \\
Anthracene/anthracene-d10 & 1.040747 \\
Fluoranthene/anthracene-d10 & 0.995174 \\
Pyrene/pyrene-d10 & 0.869273 \\
Benz[a]anthracene/chrysene-d12 & 0.914417 \\
Chrysene/chrysene-d12 & 0.951355 \\
Benzo[b]fluoranthene/benzo[a]pyrene-d12 & 1.07192 \\
Benzo[k]fluoranthene/benzo[a]pyrene-d12 & 0.77792 \\
Benzo[a]pyrene/benzo[a]pyrene-d12 & 0.878973 \\
Indeno[1,2,3-cd]pyrene/indeno[1,2,3-cd]pyrene-d12 & 1.151286 \\
Dibenz[a, $h$ ]anthracene/dibenz[a,h]anthracene-d14 & 1.009788 \\
Benzo[ghi]perylene/benzo[ghi]perylene-d12 & 1.158155 \\
\hline
\end{tabular}

PAHs were eluted at the retention times shown in Table 6. The ions used for the SIM detection and quantitation of each PAH are also indicated in Table 6.

A typical chromatogram collected in SIM mode generated from the $500 \mu \mathrm{g} / \mathrm{mL}$ standard of all analyzed PAHs is shown in Figure 1. Deuterated and non deuterated PAHs (Supelco, Bellefonte, PA 16823-0048 USA) were used to prepare the standards. Figure 1 also shows the variation in the retention time of different PAHs as a function of their molecular weight. A chromatogram, generated from a 3R4F cigarette (Level 0 phytol added) smoked under 35/60 type conditions, is shown in Figure 2. As shown in Figure 1, the separation of the analyzed PAHs is very good. Figure 2 shows that the cleanup procedure is efficient and several peaks of PAHs can be clearly seen.

For the quantitation of PAHs, the peak areas of the compounds to be analyzed were normalized by the area of the internal standards and further multiplied by an average response factor $\mathrm{F}$. The formula to measure concentrations was the following:

$$
\mathrm{PAH}_{\mathrm{cig}}=\left(\frac{\text { Area }_{\text {PAH analyte }}}{F \cdot \text { Area }_{d-I S}}\right)\left(\frac{\text { Conc }_{d-I S}}{\text { No. of smoked cigarettes }}\right) \text { [2] }
$$

The value of the response factor $\mathrm{F}$ was calculated using standards. The first step in the calculation of $F$ was to divide the peak areas of each individual deuterated $\mathrm{PAH}$ standards $\left(\right.$ Area $\left._{\text {PAH-d-standard }}\right)$ by the peak area of a nondeuterated standard (Area $\mathrm{PAH}_{\mathrm{PA} \text { standard }}$ ) with the same concentration as the deuterated one and obtain $F_{i}$ values by the formula:

$$
F_{\mathrm{i}}=\frac{\text { Area }_{\text {PAH standard }}}{\text { Area }_{\text {PAH - d standard }}}
$$

The final $F$ values were obtained as an average $F_{i}$ values generated for four different concentrations. The values for the response factors $\mathrm{F}$ are shown in Table 7. As expected, the response factors are close to 1.0 , but some variation is still present. 


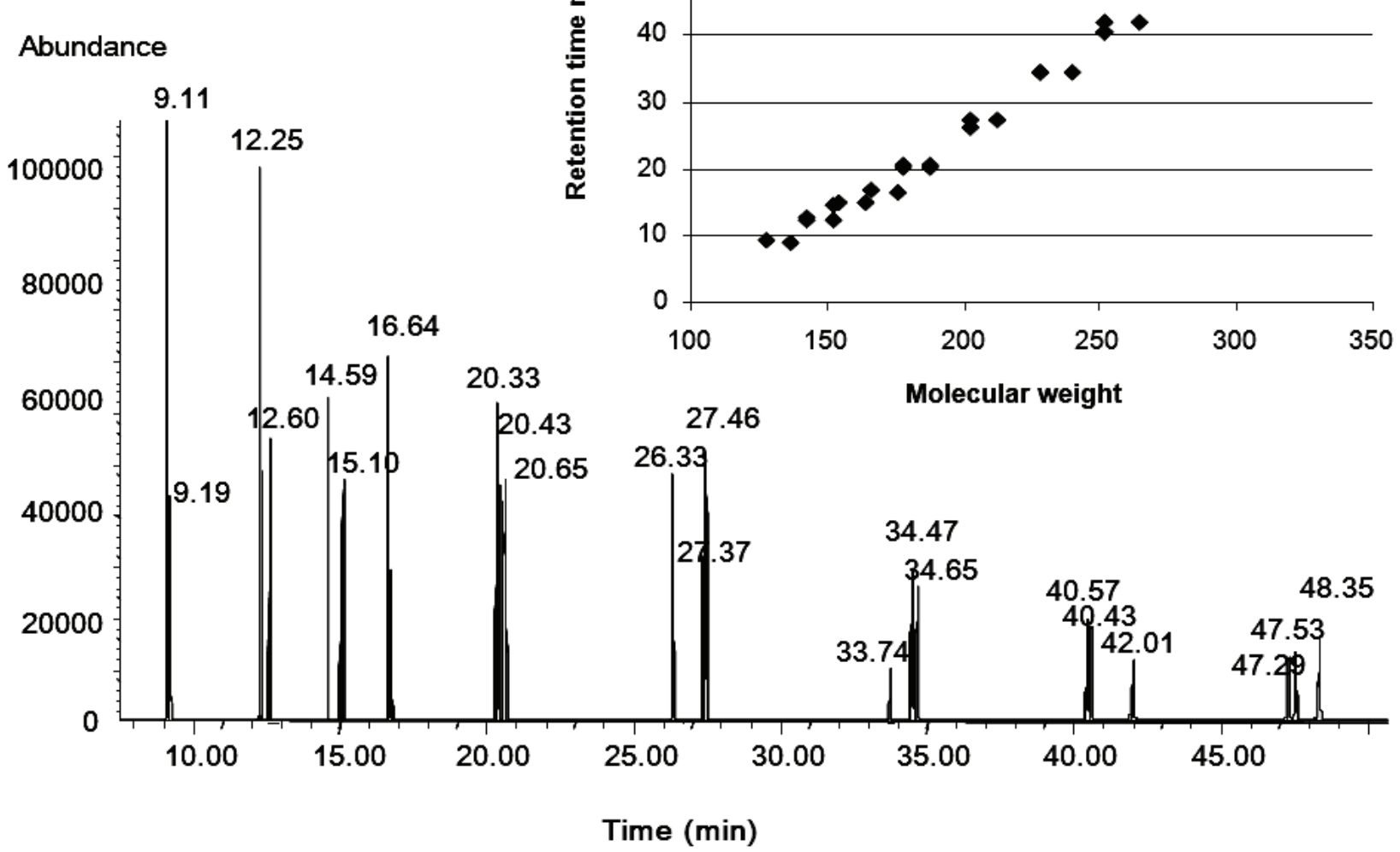

Figure 1. Chromatogram collected in SIM mode from a solution of PAH standards with the concentration of $500 \mu \mathrm{g} / \mathrm{mL}$

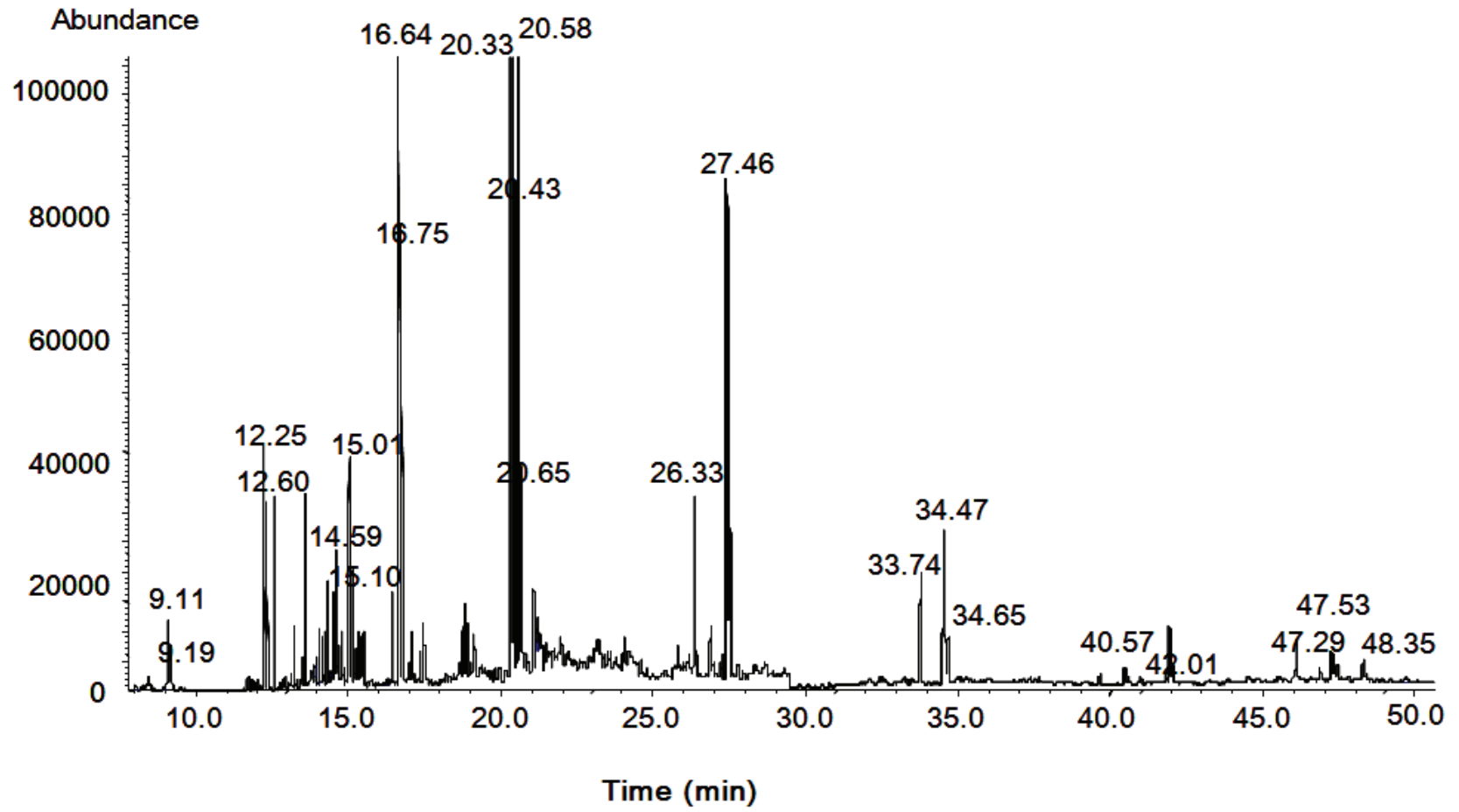

Figure 2. Chromatogram collected in SIM mode for the smoke of 3R4F cigarettes 
Table 8. Parameters used for the GC/MS on-line analysis of pyrolyzates

\begin{tabular}{lc}
\hline Parameter & Description \\
\hline GC column & DB- $1701^{\mathrm{a}}$ \\
Column dimensions & $60 \mathrm{~m}$ long, $0.25 \mathrm{~mm}$ id. \\
Film thickness & $1.0 \mu \mathrm{m}$ \\
Initial oven temperature & $37^{\circ} \mathrm{C}$ \\
Initial time & $4.0 \mathrm{~min}$ \\
Oven ramp rate & $2{ }^{\circ} \mathrm{C} / \mathrm{mm}$ \\
Oven final first ramp & $60^{\circ} \mathrm{C}$ \\
Final time first ramp & $0 \mathrm{~min}$ \\
Oven ramp rate & $5{ }^{\circ} \mathrm{C} / \mathrm{mm}$ \\
Oven final temperature & $280^{\circ} \mathrm{C}$ \\
Final time & $20 \mathrm{~min}$ \\
Total run time & $75.5 \mathrm{~min}$ \\
Inlet temperature & $280^{\circ} \mathrm{C}$ \\
Inlet mode & $\mathrm{Split}$ \\
Carrier gas & $\mathrm{Helium}$ \\
Flow mode & $\mathrm{Constant} \mathrm{flow}$ \\
Flow rate & $1.1 \mathrm{~mL} / \mathrm{min}$ \\
Nominal initial pressure & $17.5 \mathrm{psi}$ \\
Split ratio & $70: 1$ \\
Split flow & $76.0 \mathrm{~mL} / \mathrm{min}$ \\
GC outlet & $\mathrm{MSD}$ \\
Outlet pressure & $\mathrm{Vacuum}$ \\
MSD transfer line temperature & $280^{\circ} \mathrm{C}$ \\
lon source temperature & $230^{\circ} \mathrm{C}$ \\
Quadrupole temp. & $150^{\circ} \mathrm{C}$ \\
MSD EM offset & $250 \mathrm{~V}$ \\
MSD solvent delay & $2.0 \mathrm{~min}$ \\
MSD acquisition mode & $\mathrm{TIC}$ \\
Mass range & $29-550 \mathrm{a} . \mathrm{u}$. \\
\hline & \\
&
\end{tabular}

a The DB-1701 column was purchased from J\&W Scientific, Folsom, CA 95630-4714 USA

\section{Pyrolysis conditions for phytol and chlorophyll a}

Pyrolysis results for phytol and chlorophyll $a$ were generated for further comparison. For performing the pyrolysis, a filament pyrolyzer Pyroprobe 2000 with an AS 2500 autosampler (CDS Analytical, CDS, Oxford, PA, 19363, USA) on line with an Agilent GC/MS system has been used. Pyrolysis conditions included $\mathrm{T}_{\mathrm{eq}}=900{ }^{\circ} \mathrm{C}, \beta=$ $10^{\circ} \mathrm{C} / \mathrm{ms}, \mathrm{THT}=10 \mathrm{~s}$, and $\mathrm{T}_{\text {hou }}=280^{\circ} \mathrm{C}\left(\mathrm{T}_{\mathrm{eq}}=\right.$ equilibrium temperature, $\beta=$ heating rate, THT = total heating time, and $\mathrm{T}_{\text {hou }}=$ housing temperature). The analysis of pyrolyzate was done by GC/MS under conditions given in Table 8 .

\section{RESULTS AND DISCUSSION}

Comparison of $P A H$ s results for $2 R 4 F$ and $3 R 4 F$ cigarettes

The first step of the study was the verification of the results for PAHs between 2R4F and 3R4F cigarettes with no addition of phytol, and literature results for $2 \mathrm{R} 4 \mathrm{~F}$ cigarette (10). These results expressed in ng/cig are given in Table 9. The values from this study were obtained as an average of two analyses. The corresponding relative standard deviations (RSD\%) for the averages shown in Table 9 are given in Table 10.

As shown in Table 9, the results for PAHs are not significantly different for $2 \mathrm{R} 4 \mathrm{~F}$ cigarettes and for $3 \mathrm{R} 4 \mathrm{~F}$ cigarettes. Also, the results for $2 \mathrm{R} 4 \mathrm{~F}$ cigarette smoked under $35 / 60$ conditions are in good agreement with the results reported in the literature. The values for measured PAHs obtained when smoking was performed under intensive conditions $(60 / 30)$ are as expected, 2.5 to 3.0 times higher than the levels generated by $35 / 60$ smoking. Except a few values the RSD \% for the measurements are also below $10 \%$, as shown in Table 10 .

Table 9. The results for PAHs expressed in $\mathrm{ng} / \mathrm{cig}$ for $35 / 60$ and for $60 / 30$ smoking conditions on $2 \mathrm{R} 4 \mathrm{~F}$ and $3 \mathrm{R} 4 \mathrm{~F}$ cigarettes

\begin{tabular}{|c|c|c|c|c|c|}
\hline \multirow[b]{2}{*}{ Compound } & \multicolumn{2}{|c|}{$35 / 60$ smoking } & \multicolumn{2}{|c|}{$60 / 30$ smoking } & \multirow{2}{*}{$\begin{array}{l}\text { 35/60 smoking } \\
\text { 2R4F (Ref. 10) }\end{array}$} \\
\hline & 2R4F & 3R4F & 2R4F & 3R4F & \\
\hline Naphthalene & 355.4 & 345.4 & 949.1 & 1017.2 & 310.0 \\
\hline 2-Me naphthalene & 383.3 & 383.7 & 1001.8 & 1029.7 & 366.4 \\
\hline 1-Me naphthalene & 323.7 & 355.9 & 872.0 & 891.8 & 396.5 \\
\hline Acenaphthylene & 69.8 & 68.9 & 183.5 & 181.8 & 69.9 \\
\hline Acenaphthene & 53.2 & 49.8 & 116.1 & 107.6 & 35.9 \\
\hline Fluorene & 179.7 & 173.9 & 411.1 & 402.4 & 169.8 \\
\hline Phenanthrene & 136.6 & 137.5 & 309.8 & 293.1 & 146.8 \\
\hline Anthracene & 68.8 & 55.7 & 176.2 & 166.1 & 52.5 \\
\hline Fluoranthene & 64.5 & 54.3 & 173.2 & 178.5 & 51.0 \\
\hline Pyrene & 43.4 & 43.4 & 92.7 & 89.5 & 45.0 \\
\hline Benz[a]anthracene & 13.7 & 13.8 & 29.6 & 26.8 & 16.6 \\
\hline Chrysene & 15.6 & 15.8 & 32.6 & 31.4 & 16.6 \\
\hline Benzo[b]fluoranthene & 5.2 & 5.2 & 11.4 & 10.3 & 5.4 \\
\hline Benzo[k]fluoranthene & 1.7 & 1.7 & 3.9 & 3.3 & 1.37 \\
\hline Benzo[a]pyrene & 6.7 & 7.2 & 15.5 & 14.2 & 9.2 \\
\hline Indeno[1,2,3-cd]pyrene & 2.4 & 2.4 & 5.0 & 4.4 & 1.5 \\
\hline Dibenz $[a, h]$ anthracene & 1.4 & 1.7 & 2.9 & 2.5 & 0.6 \\
\hline Benzo[ghi]perylene & 1.6 & 1.9 & 4.7 & 4.0 & 2.0 \\
\hline
\end{tabular}


Table 10. Relative standard deviations (RSD \%) for the results for PAHs given in Table 9

\begin{tabular}{|c|c|c|c|c|c|}
\hline \multirow[b]{2}{*}{ Compound } & \multicolumn{2}{|c|}{ 35/60 smoking } & \multicolumn{2}{|c|}{$60 / 30$ smoking } & \multirow{2}{*}{$\begin{array}{l}\text { 35/60 smoking } \\
\text { 2R4F (Ref. 10) }\end{array}$} \\
\hline & 2R4F & 3R4F & 2R4F & 3R4F & \\
\hline Naphthalene & 2.2 & 1.9 & 13.2 & 3.6 & 4.9 \\
\hline 2-Me naphthalene & 1.8 & 2.0 & 3.2 & 1.2 & 1.5 \\
\hline 1-Me naphthalene & 4.4 & 8.8 & 5.8 & 3.1 & 2.5 \\
\hline Acenaphthylene & 3.7 & 2.0 & 13.0 & 15.8 & 3.9 \\
\hline Acenaphthene & 9.6 & 0.5 & 3.3 & 3.2 & 3.6 \\
\hline Fluorene & 7.5 & 3.0 & 2.2 & 1.0 & 1.8 \\
\hline Phenanthrene & 2.4 & 3.3 & 3.2 & 1.3 & 2.3 \\
\hline Anthracene & 13.4 & 1.0 & 0.5 & 1.1 & 1.4 \\
\hline Fluoranthene & 4.0 & 5.3 & 8.9 & 3.9 & 2.6 \\
\hline Pyrene & 4.7 & 4.8 & 2.0 & 1.7 & 5.6 \\
\hline Benz[a]anthracene & 4.3 & 6.0 & 0.4 & 3.1 & 3.0 \\
\hline Chrysene & 5.0 & 6.6 & 2.2 & 1.0 & 8.1 \\
\hline Benzo[b]fluoranthene & 5.1 & 5.2 & 6.3 & 4.8 & 8.3 \\
\hline Benzo[k]fluoranthene & 8.4 & 12.2 & 9.1 & 8.9 & 8.0 \\
\hline Benzo[a]pyrene & 1.6 & 8.0 & 6.0 & 4.1 & 4.6 \\
\hline Indeno[1,2,3-cd]pyrene & 11.6 & 12.9 & 7.2 & 4.1 & 8.7 \\
\hline Dibenz[a,h]anthracene & 9.2 & 11.7 & 5.8 & 7.1 & 3.8 \\
\hline Benzo[ghi]perylene & 9.0 & 7.7 & 3.6 & 4.4 & 5.2 \\
\hline
\end{tabular}

Comparison of levels of PAHs for cigarettes without and with the addition of phytol

The levels of PAHs obtained from the 3R4F cigarettes with different levels of added phytol when smoking was done under $35 / 60$ conditions are given in Table 11 . The corresponding RSD \% for individual measurements is given in Table 12. As shown in Table 11, the variation in the level of individual PAHs for the cigarettes with different levels of phytol, shows a certain increase between the cigarettes with Level 0 and Level 15 of phytol. However, this increase is not relevant, particularly for key PAHs such as benz $[a]$ anthracene, benzo[b]fluoranthene, benzo $[k]$ fluoranthene, indeno[1,2,3-cd]pyrene and dibenzo$[a, h]$ anthracene, where the RSD \% between levels is in the same range of values as the RSD \% for duplicate measurements. The largest relative increase between Level 0 and Level 15 is seen for anthracene and fluoranthene.

The graph showing the variation in total PAHs level for $35 / 60$ smoking as a function of added phytol is shown in Figure 3. Statistical evaluation of the dependence of total PAHs generated by $35 / 60$ smoking and the added level of phytol showed that the hypothesis of a zero slope for the

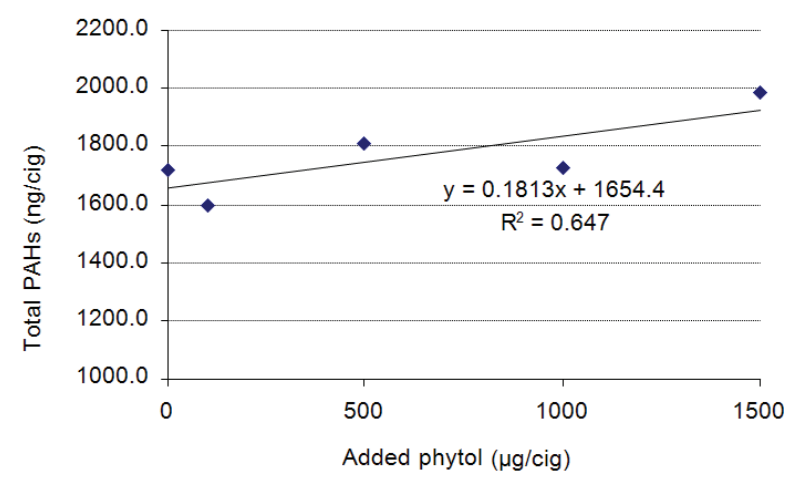

Figure 3. Total PAHs as a function of added phytol on 3R4F cigarettes (35/60 smoking) dependence line cannot be rejected (with a $p=0.101$ ).

The same experiment as previously described for $35 / 60$ smoking was repeated for intensive smoking (60/30). The results for levels of PAHs obtained from the 3R4F cigarettes with different levels of added phytol when smoking was done in 60/30 conditions are given in Table 13. The corresponding RSD \% for individual measurements is given in Table 14. As shown in Table 13, the increase in individual PAHs level for 60/30 smoking is less pronounced compared to $35 / 60$ smoking. This increase is in the same range of variation as the RSD \% levels between duplicates of the same sample.

The graph showing the variation in total PAHs level for $60 / 30$ smoking as a function of added phytol is shown in Figure 4. Statistical evaluation of the dependence of total PAHs generated by 60/30 smoking and the added level of phytol showed that the hypothesis of a zero slope for the dependence line cannot be rejected (with a $p=0.626$ ).

As seen from Tables 11 and 13, as well as from Figures 3 and 4 , the addition of phytol to 3R4F cigarette does not increase the level of PAHs in smoke. An increase of about $14 \%$ in the total PAHs level for 3R4F cigarette smoked under $35 / 60$ conditions, can be the result of a random

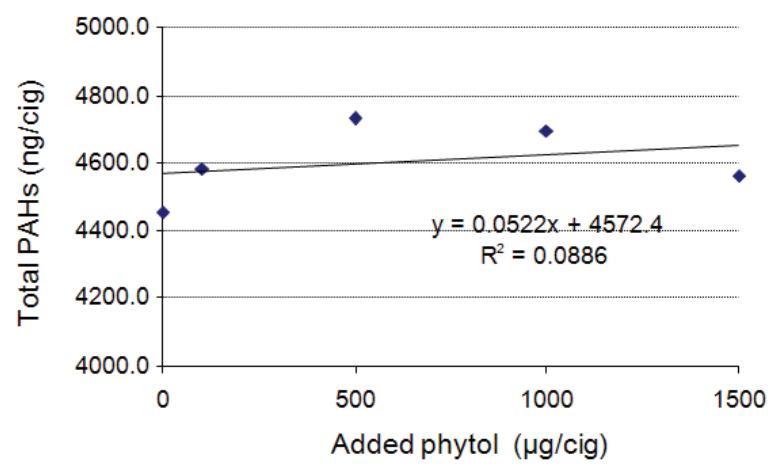

Figure 4. Total PAHs as a function of added phytol on 3R4F cigarettes (60/30 smoking) 
Table 11. The levels of PAHs in ng/cig in 3R4F cigarettes injected with different levels of phytol (average of two measurements) and the RSD\% between cigarettes with different levels of phytol (35/60 smoking)

\begin{tabular}{|c|c|c|c|c|c|c|}
\hline Compound & Level 0 & Level 1 & Level 5 & Level 10 & Level $15^{a}$ & $\begin{array}{c}\text { RSD\% between } \\
\text { levels }\end{array}$ \\
\hline Naphthalene & 345.4 & 306.9 & 356.8 & 330.7 & 399.7 & 9.9 \\
\hline 2-Me naphthalene & 383.7 & 344.8 & 392.8 & 370.7 & 424.8 & 7.7 \\
\hline 1-Me naphthalene & 355.9 & 319.4 & 381.8 & 376.2 & 409.0 & 9.1 \\
\hline Acenaphthylene & 68.9 & 64.2 & 68.9 & 66.6 & 81.3 & 9.5 \\
\hline Acenaphthene & 49.8 & 47.0 & 50.4 & 47.2 & 56.2 & 7.5 \\
\hline Fluorene & 173.9 & 163.4 & 176.2 & 169.5 & 190.1 & 5.7 \\
\hline Phenanthrene & 137.5 & 128.2 & 134.5 & 130.4 & 159.3 & 9.0 \\
\hline Anthracene & 55.7 & 69.7 & 78.5 & 74.4 & 85.8 & 15.4 \\
\hline Fluoranthene & 54.3 & 67.9 & 76.7 & 72.3 & 78.5 & 13.8 \\
\hline Pyrene & 43.4 & 41.1 & 42.9 & 41.3 & 46.8 & 5.2 \\
\hline Benz[a]anthracene & 13.8 & 12.8 & 13.3 & 13.0 & 14.6 & 5.5 \\
\hline Chrysene & 15.8 & 14.8 & 15.0 & 14.9 & 16.2 & 4.0 \\
\hline Benzo[b]fluoranthene & 5.2 & 4.9 & 5.1 & 5.0 & 5.7 & 5.8 \\
\hline Benzo[k]fluoranthene & 1.7 & 1.7 & 1.6 & 1.8 & 2.0 & 7.6 \\
\hline Benzo[a]pyrene & 7.2 & 6.6 & 6.8 & 6.8 & 7.4 & 4.8 \\
\hline Indeno[1,2,3-cd]pyrene & 2.4 & 2.3 & 2.4 & 2.4 & 2.6 & 3.9 \\
\hline Dibenz $[a, h]$ anthracene & 1.7 & 1.5 & 1.4 & 1.5 & 1.7 & 9.5 \\
\hline Benzo[ghi]perylene & 1.9 & 1.7 & 1.7 & 1.7 & 1.9 & 6.0 \\
\hline TOTAL PAHs & 1718.3 & 1599.0 & 1806.7 & 1726.5 & 1983.6 & \\
\hline
\end{tabular}

a Only one replicate was generated for Level 15.

Table 12. Relative standard deviations (RSD\%) of individual values given in Table 11 for PAHs measurements

\begin{tabular}{lrrrr|r}
\hline Compound & Level 0 & Level 1 & Level 5 & Level 10 \\
\hline Naphthalene & 1.9 & 6.0 & 8.8 & 6.4 \\
2-Me naphthalene & 2.0 & 2.9 & 9.2 & 4.1 \\
1-Me naphthalene & 8.8 & 8.7 & 12.4 & 3.1 \\
Acenaphthylene & 2.0 & 6.5 & 2.0 & 4.9 \\
Acenaphthene & 0.5 & 2.0 & 5.0 & 0.5 \\
Fluorene & 3.0 & 1.4 & 5.1 & 3.7 \\
Phenanthrene & 3.3 & 1.9 & 2.5 & 4.3 \\
Anthracene & 1.0 & 3.0 & 2.3 & 4.8 \\
Fluoranthene & 5.3 & 1.3 & 2.0 & 3.0 \\
Pyrene & 4.8 & 0.3 & 5.6 & 3.6 \\
Benz[a]anthracene & 6.0 & 0.1 & 3.1 & 3.6 \\
Chrysene & 6.6 & 2.0 & 5.3 & 3.2 \\
Benzo[b]fluoranthene & 5.2 & 0.7 & 5.8 & 1.3 \\
Benzo[k]fluoranthene & 12.2 & 9.7 & 4.7 & 8.5 \\
Benzo[a]pyrene & 8.0 & 3.7 & 7.1 & 8.2 \\
Indeno[1,2,3-cd]pyrene & 12.9 & 6.2 & 5.2 & 8.5 \\
Dibenz[a, $h$ ]anthracene & 11.7 & 12.8 & 7.5 & 7.4 \\
Benzo[ghi]perylene & 7.7 & 13.8 & 10.0 & 8.5 \\
\hline & & & & \\
\hline
\end{tabular}

variation in the measurement of PAHs level, can be caused by the unintentional modifications of the cigarettes when injected with phytol, or can be a real small increase in the PAHs deliveries. However, the $14 \%$ increase in the PAHs values between Level 0 addition of phytol and Level 15 addition of phytol is much lower than the expected increase of about $100 \%$ based on literature findings (8).

A plausible explanation for this result is the difference between the conditions of pyrolysis of phytol in a cigarette and pyrolysis in a flow through or a static system.
Comparison of pyrolysis results between phytol and chlorophyll a

Since phytol is not present in large level as a free compound in tobacco, but it is connected as an ester to form chlorophyll, individual pyrolysis experiments were performed on both phytol and on chlorophyll $a$ to compare the results between the two compounds and find if the pyrolyzates show significant differences. Pyrolysis of phytol was performed on $0.60 \mathrm{mg}$ compound as described in the experimental part. The resulting pyrogram is given in Figure 5 and the peak identification based on the mass spectra of the compounds is given in Table 15. The calculation of the mol \% was obtained by dividing the individual peak areas in the chromatogram by total area and by the compound molecular weight. As shown in Table 15, almost $50 \%$ (mol) of the phytol does not decompose in the experimental conditions selected for the pyrolysis. This is probably caused by the evaporation of phytol before it reaches the decomposition temperature and its rapid transfer into the GC/MS system. For phytol the reaction occurring with hydrogen elimination and formation of (2E)3,7,11,15-tetramethylhexadec-2-enal as expected for an alcohol does take place, but the compound is present in the pyrolyzate at only $0.2 \%(\mathrm{~mol})$ from the total pyrolyzate composition. Elimination of water is unlikely without rearrangement of the double bond from the 2-position. In the case of phytol, most pyrolysis products are various fragments of phytol molecule from along the hydrocarbon chain. Pyrolysis products are more similar to those of a long-chain hydrocarbon than those of a typical alcohol. This is common for a large molecule where the functional group is only a small part of a much larger structure. 
Table 13. The levels of PAHs in ng/cig in 3R4F cigarettes injected with different levels of phytol (average of two measurements) and the RSD\% between cigarettes with different levels of phytol (60/30 smoking)

\begin{tabular}{|c|c|c|c|c|c|c|}
\hline Compound & Level 0 & Level 1 & Level 5 & Level 10 & Level 15 & $\begin{array}{c}\text { RSD \% between } \\
\text { levels }\end{array}$ \\
\hline Naphthalene & 1017.2 & 1036.7 & 1081.4 & 1109.2 & 1068.7 & 3.5 \\
\hline 2-Me naphthalene & 1029.7 & 1009.2 & 1088.2 & 1039.8 & 1031.3 & 2.9 \\
\hline 1-Me naphthalene & 891.8 & 1007.9 & 973.6 & 980.3 & 919.9 & 8.4 \\
\hline Acenaphthylene & 181.8 & 174.8 & 177.8 & 185.0 & 174.5 & 3.1 \\
\hline Acenaphthene & 107.6 & 120.2 & 114.4 & 115.9 & 107.5 & 2.1 \\
\hline Fluorene & 402.4 & 390.3 & 421.3 & 410.3 & 410.4 & 3.2 \\
\hline Phenanthrene & 293.1 & 301.2 & 317.2 & 314.4 & 309.1 & 4.1 \\
\hline Anthracene & 166.1 & 173.8 & 178.0 & 173.8 & 170.9 & 2.5 \\
\hline Fluoranthene & 178.5 & 174.9 & 185.0 & 161.2 & 165.8 & 7.2 \\
\hline Pyrene & 89.5 & 94.0 & 93.6 & 95.4 & 94.4 & 3.7 \\
\hline Benz[a]anthracene & 26.8 & 29.1 & 28.7 & 31.0 & 31.0 & 5.6 \\
\hline Chrysene & 31.4 & 33.7 & 33.9 & 34.3 & 34.0 & 5.4 \\
\hline Benzo[b]fluoranthene & 10.3 & 9.1 & 10.1 & 10.4 & 10.7 & 9.2 \\
\hline Benzo[k]fluoranthene & 3.3 & 3.2 & 3.1 & 3.9 & 3.8 & 3.6 \\
\hline Benzo[a]pyrene & 14.2 & 15.3 & 14.8 & 16.1 & 16.1 & 8.1 \\
\hline Indeno[1,2,3-cd]pyrene & 4.4 & 4.4 & 4.3 & 4.9 & 4.9 & 8.5 \\
\hline Dibenz[a,h]anthracene & 2.5 & 2.0 & 2.2 & 2.5 & 2.5 & 7.1 \\
\hline Benzo[ghi]perylene & 4.0 & 4.2 & 3.9 & 4.9 & 4.7 & 9.3 \\
\hline Total PAHs & 4454.7 & 4584.0 & 4731.7 & 4693.2 & 4560.2 & \\
\hline
\end{tabular}

Table 14. Relative standard deviations (RSD\%) of individual values given in Table 13 for PAHs measurements

\begin{tabular}{|c|c|c|c|c|c|}
\hline Compound & Level 0 & Level 1 & Level 5 & Level 10 & Level 15 \\
\hline Naphthalene & 3.6 & 1.8 & 2.4 & 3.4 & 2.1 \\
\hline 2-Me naphthalene & 1.2 & 5.1 & 1.7 & 0.8 & 1.8 \\
\hline 1-Me naphthalene & 3.1 & 5.7 & 5.2 & 4.2 & 4.1 \\
\hline Acenaphthylene & 15.8 & 2.9 & 3.0 & 7.3 & 1.5 \\
\hline Acenaphthene & 3.2 & 5.1 & 4.9 & 11.5 & 1.4 \\
\hline Fluorene & 1.0 & 3.6 & 1.9 & 1.8 & 1.9 \\
\hline Phenanthrene & 1.3 & 5.4 & 5.0 & 2.2 & 4.8 \\
\hline Anthracene & 1.1 & 8.4 & 4.8 & 1.5 & 3.6 \\
\hline Fluoranthene & 3.9 & 9.5 & 1.1 & 2.2 & 4.0 \\
\hline Pyrene & 1.7 & 7.8 & 3.3 & 2.4 & 4.3 \\
\hline Benz[a]anthracene & 3.1 & 7.8 & 3.7 & 5.4 & 5.4 \\
\hline Chrysene & 1.0 & 7.1 & 5.8 & 2.1 & 3.2 \\
\hline Benzo[b]fluoranthene & 4.8 & 0.6 & 3.0 & 9.2 & 3.5 \\
\hline Benzo[k]fluoranthene & 8.9 & 3.1 & 2.9 & 5.1 & 8.1 \\
\hline Benzo[a]pyrene & 4.1 & 4.2 & 0.2 & 5.8 & 5.5 \\
\hline Indeno[1,2,3-cd]pyrene & 4.1 & 2.8 & 0.8 & 4.5 & 4.6 \\
\hline Dibenz[a,h]anthracene & 7.1 & 9.5 & 4.0 & 9.8 & 13.8 \\
\hline Benzo[ghi]perylene & 4.4 & 3.8 & 3.4 & 1.3 & 4.2 \\
\hline
\end{tabular}

The resulting pyrogram obtained at $900{ }^{\circ} \mathrm{C}$ from $0.2 \mathrm{mg}$ chlorophyll $a$ is shown in Figure 6, and the peak identification is given in Table 16. The calculation of the mol \% was obtained by dividing the individual peak areas in the chromatogram by total area and by the compound molecular weight. As shown in Table 16, fragment molecules are generated from both the chlorin ring and from the phytol side chain. Neophytadiene (the alkene generated from phytol dehydration) is one important component of the pyrolyzate. Several substituted pyrroles are also present in the pyrolyzate. Due to the high molecular weight and lack of volatility, chlorophyll pyrolysis at $900^{\circ} \mathrm{C}$ generated a relatively large proportion of small molecules such as $\mathrm{CO}_{2}$, propene, and 2methylpropene. However, the main pyrolysis products generated from the phytol moiety from chlorophyll are very similar to those generated from pure phytol.

\section{CONCLUSIONS}

This study evaluated the formation of PAHs when several levels of phytol were added on 3R4F cigarettes. The cigarettes were smoked under two different smoking conditions, 35/60 and intensive 60/30. The increase in the PAHs level upon phytol addition was not significant. A 


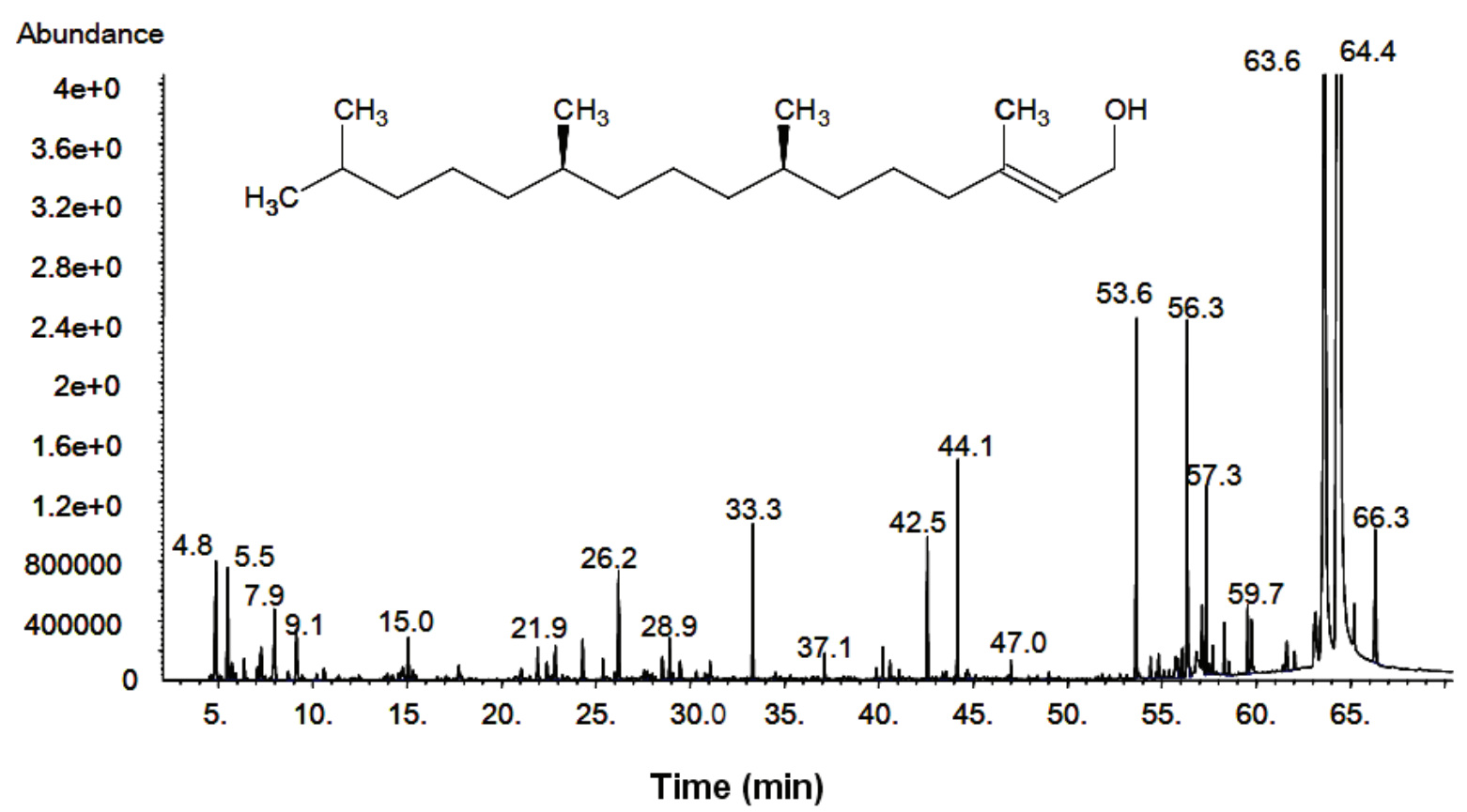

Figure 5. Pyrogram of phytol at $900^{\circ} \mathrm{C}$

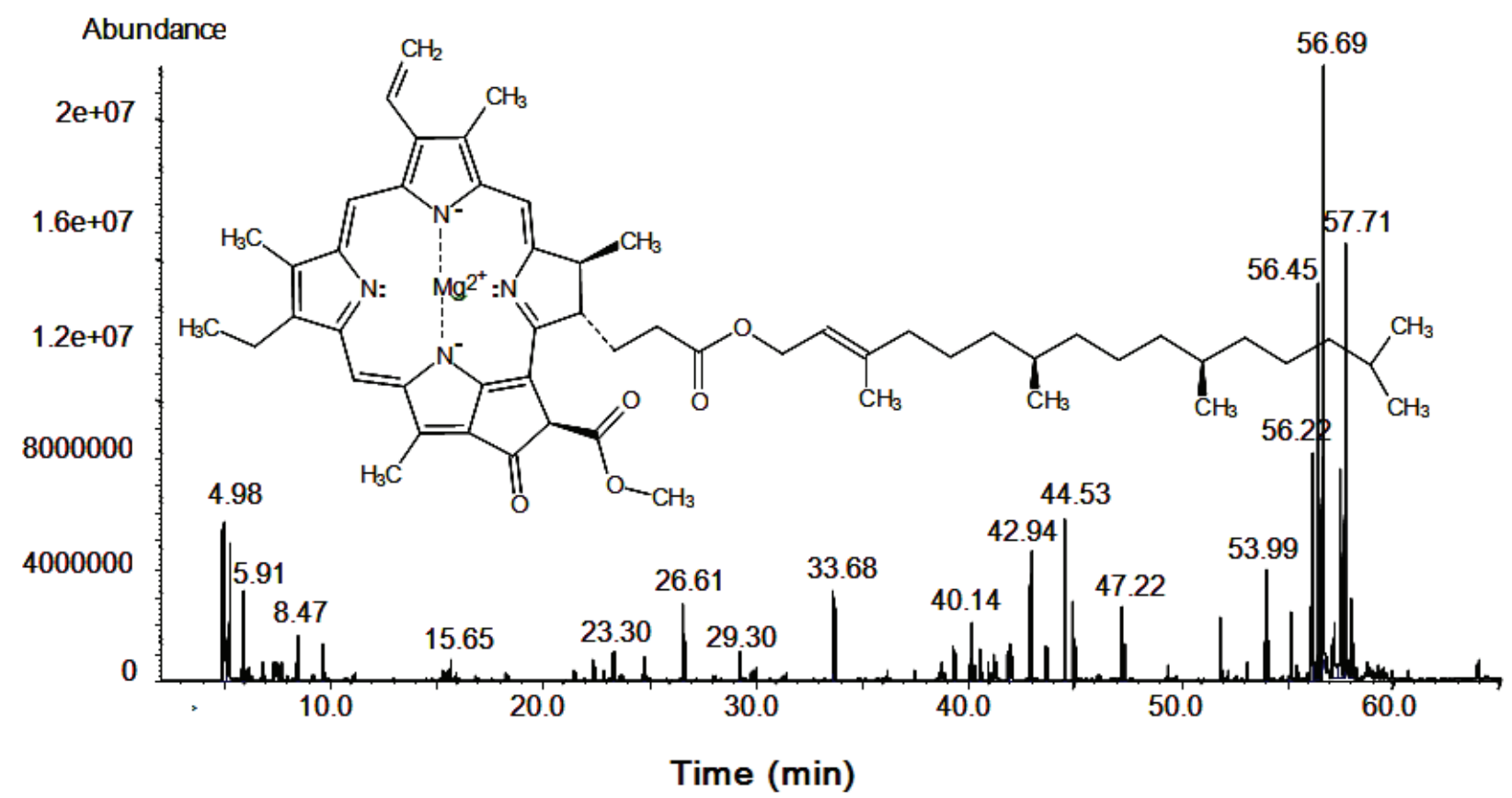

Figure 6. Pyrogram obtained at $900{ }^{\circ} \mathrm{C}$ for chlorophyll a $(\mathrm{MW}=823$ )

statistical evaluation of the dependence of total PAHs and the added level of phytol showed that the hypothesis of a zero slope for the dependence line cannot be rejected (with a $p=0.101$ for $35 / 60$ smoking and $p=0.626$ for $60 / 30$ smoking). Still, for 35/60 smoking conditions, an increase of about $14 \%$ in total levels of PAHs was noticed when the added phytol level was $1.5 \mathrm{mg}$ phytol per cigarette (ten times typical level in tobacco leaf). However, this increase was not necessarily determined by the phytol addition, and can be caused by random errors (as the statistical analysis would indicate) or by the modification of cigarettes during phytol addition. Also, the level is much lower than the expected $100 \%$ increase in the PAHs level, based on literature prediction (8). Intensive smoking did not show an increase in PAHs level. Flash pyrolysis of free phytol and of chlorophyll $a$ provided results that would indicate that phytol bound in chlorophyll is not likely to generate different PAHs level compared to free phytol. The study showed that phytol is not a significant contributor/precursor to the PAHs formation in cigarette smoke. 
Table 15. Identification of the main peaks in the chromatogram shown in Figure 5 for the pyrolysis of phytol. Hydrogen, CO, $\mathrm{CO}_{2}$, methane, ethane, and water are not included ('?' indicates a tentative/possible compound assignment).

\begin{tabular}{|c|c|c|c|c|c|}
\hline No & Compound & Retention time (min) & MW & CAS-No. & Mol \% pyrolyzate \\
\hline 1 & Propene & 4.88 & 42 & $115-07-1$ & 7.17 \\
\hline 2 & Formaldehyde & 5.10 & 30 & $50-00-0$ & 0.09 \\
\hline 3 & Isobutane & 5.20 & 58 & $75-28-5$ & 0.02 \\
\hline 4 & 1-Butene & 5.51 & 56 & $106-98-9$ & 5.12 \\
\hline 5 & 1,3-Butadiene & 5.74 & 54 & $106-99-0$ & 0.97 \\
\hline 6 & 2-Butene & 5.93 & 56 & $107-01-7$ & 0.30 \\
\hline 7 & 3-Methyl-2-butene & 6.38 & 70 & $563-45-1$ & 0.72 \\
\hline 8 & 1-Pentene & 7.08 & 70 & $109-67-1$ & 0.50 \\
\hline 9 & 3-Methyl-1-butene & 7.27 & 70 & $563-45-1$ & 1.19 \\
\hline 10 & 1,2-Dimethylcyclopropane & 7.5 & 70 & $930-18-7$ & 0.17 \\
\hline 11 & 2-Methyl-1,3-butadiene (isoprene) & 7.99 & 68 & $78-79-5$ & 3.05 \\
\hline 12 & 1,3-Pentadiene & 8.72 & 68 & $504-60-9$ & 0.31 \\
\hline 13 & 4-Methyl-1-pentene & 9.16 & 84 & $691-37-2$ & 1.64 \\
\hline 14 & Cyclopentadiene & 9.44 & 66 & $542-92-7$ & 0.18 \\
\hline 15 & 2-Methyl-1,4-pentadiene & 10.23 & 82 & $763-30-4$ & 0.22 \\
\hline 16 & 1-Hexene & 10.62 & 84 & $592-41-6$ & 0.38 \\
\hline 17 & 4-Methyl-2-pentene & 11.40 & 84 & $691-38-3$ & 0.24 \\
\hline 18 & 3-Methyl-1,3-pentadiene (E) & 12.47 & 82 & $2787-43-1$ & 0.14 \\
\hline 19 & 2,3-Dimethyl-1-pentene & 13.80 & 98 & 2213-32-3 & 0.11 \\
\hline 20 & 3-Methyl-1-hexene & 13.98 & 98 & $3404-61-3$ & 0.20 \\
\hline 21 & 4-Methyl-1,3-pentadiene & 14.25 & 82 & $926-56-7$ & 0.22 \\
\hline 22 & 1-Methylcyclopentene & 14.57 & 82 & $693-89-0$ & 0.24 \\
\hline 23 & 1-Methyl-1,3-cyclopentadiene & 14.78 & 80 & $96-39-9$ & 0.57 \\
\hline 24 & 4-Methyl-1-hexene & 15.08 & 98 & $3769-23-1$ & 1.18 \\
\hline 25 & 3-Methylenecyclopentene & 15.33 & 80 & 930-26-7 & 0.33 \\
\hline 26 & 5-Methyl-1,3-cyclopentadiene & 15.47 & 80 & 96-38-8 & 0.17 \\
\hline 27 & 2-Methyl-1,5-hexadiene & 16.62 & 96 & $4049-81-4$ & 0.10 \\
\hline 28 & 1,3-Cyclohexadiene & 17.09 & 80 & $592-57-4$ & 0.11 \\
\hline 29 & Benzene & 17.75 & 78 & $71-43-2$ & 0.58 \\
\hline 30 & 4-Methyl-1,4-hexadiene & 17.88 & 96 & $1116-90-1$ & 0.12 \\
\hline 31 & 5-Methyl-1,4-hexadiene & 20.73 & 96 & 763-88-2 & 0.13 \\
\hline 32 & 4-Methyl-1-heptene & 21.07 & 112 & $13151-05-8$ & 0.37 \\
\hline 33 & 3-Methyl-1,3,5-hexatriene ( $Z$ ) & 21.51 & 94 & 24587-27-7 & 0.15 \\
\hline 34 & 6-Methyl-2-heptene & 21.93 & 112 & $73548-72-8$ & 0.67 \\
\hline 35 & 2-Methyl-3-heptene & 22.42 & 112 & $17618-76-7$ & 0.33 \\
\hline 36 & 3-Methylcyclohexene & 22.55 & 96 & $591-48-0$ & 0.12 \\
\hline 37 & 1,3-Cycloheptadiene? & 22.73 & 94 & $4054-38-0$ & 0.14 \\
\hline 38 & 2-Methyl-1-heptene & 22.87 & 112 & $15870-10-7$ & 0.69 \\
\hline 39 & 1-Methyl-1,4-cyclohexadiene & 23.24 & 94 & $4313-57-9$ & 0.14 \\
\hline 40 & Toluene & 24.32 & 92 & $108-88-3$ & 0.88 \\
\hline 41 & 1,3-Dimethylcyclohexene & 25.4 & 110 & $2808-76-6$ & 0.38 \\
\hline 42 & 3-Methyl-1-octene & 26.02 & 126 & $13151-08-1$ & 0.12 \\
\hline 43 & 2,6-Dimethyl-1-heptene & 26.23 & 126 & $3074-78-0$ & 1.56 \\
\hline 44 & 4-Nonene? & 27.58 & 126 & 2198-23-4 & 0.15 \\
\hline 45 & 1,3-Dimethyl-2-methylene-cis-cyclohexane & 27.84 & 124 & $19781-47-6$ & 0.07 \\
\hline 46 & 1,2,3-Trimethylcyclohexane & 28.01 & 126 & $1678-97-3$ & 0.11 \\
\hline 47 & 2-Methyl-3-butenol & 28.54 & 84 & $107-86-8$ & 0.56 \\
\hline 48 & 3,7-Dimethyl-1-octene & 28.93 & 140 & $4984-01-0$ & 0.53 \\
\hline 49 & Ethylbenzene & 29.09 & 106 & $100-41-4$ & 0.17 \\
\hline 50 & 1,3-Dimethylbenzene ( $m$-xylene) & 29.48 & 106 & 108-38-3 & 0.41 \\
\hline 51 & 2-Undecine? & 30.35 & 152 & $60212-29-5$ & 0.11 \\
\hline 52 & 1,4-Dimethylbenzene ( $p$-xylene) & 30.8 & 106 & $106-42-3$ & 0.11 \\
\hline 53 & 2,6-Dimethyl-1-octene & 31.07 & 140 & $6874-29-9$ & 0.19 \\
\hline 54 & 4-Methyl-1-decene & 33.33 & 154 & $13151-29-6$ & 1.67 \\
\hline 55 & 4-Methyl-1-undecene & 37.14 & 168 & $74630-39-0$ & 0.25 \\
\hline 56 & 2,5-Dimethyl-2-undecene & 40.23 & 182 & $49622-16-4$ & 0.32 \\
\hline 57 & 7-Methyl-6-tridecene & 42.58 & 196 & $24949-42-6$ & 1.12 \\
\hline 58 & 1-Pentadecene? & 44.18 & 210 & $13360-61-7$ & 1.71 \\
\hline 59 & 3-Tetradecene? & 44.6 & 196 & $41446-68-8$ & 0.04 \\
\hline 60 & 2,6,10-Trimethyldodecane & 47 & 212 & $3891-98-3$ & 0.15 \\
\hline
\end{tabular}




\begin{tabular}{|c|c|c|c|c|c|}
\hline No & Compound & Retention time $(\mathrm{min})$ & MW & CAS-No. & Mol \% pyrolyzate \\
\hline 61 & 3,7,11,15-Tetramethyl-2-pentene & 53.66 & 266 & N/A & 2.50 \\
\hline 62 & Phytol fragment & 54.4 & 278 & $\mathrm{~N} / \mathrm{A}$ & 0.13 \\
\hline 63 & 3,7,11,15-Tetramethyl-2-hexadecene & 54.83 & 280 & $14237-73-1$ & 0.16 \\
\hline 64 & Phytol fragment & 55.74 & 278 & N/A & 0.21 \\
\hline 65 & $3,7,11,15$-Tetramethyl-2-hexadecene isomer & 55.87 & 280 & N/A & 0.12 \\
\hline 66 & $3,7,11,15$-Tetramethyl-2-hexadecene isomer & 56.09 & 280 & N/A & 0.20 \\
\hline 67 & 2-(4,8,12-Trimethyltridecyl)-1,3-butadiene neophytadiene & 56.34 & 278 & $504-96-1$ & 2.65 \\
\hline 68 & 3,7,11,15-Tetramethyl-2-hedadecen-1-ol ? & 56.85 & 296 & 102608-53-7 & 0.51 \\
\hline 69 & Eicosadiene & 57.14 & 278 & $\mathrm{~N} / \mathrm{A}$ & 0.54 \\
\hline 70 & 1,4-Eicosadiene & 57.36 & 278 & $1000131-16-3$ & 1.17 \\
\hline 71 & (2E)-3,7,11,15-Tetramethylhexadec-2-enal & 57.5 & 294 & N/A & 0.20 \\
\hline 72 & 6,10,14-Trimethyl-2-pentadecanone & 58.32 & 268 & $502-69-2$ & 0.37 \\
\hline 73 & $6,10,14$-Trimethyl-2-pentadecanone isomer & 59.56 & 268 & $\mathrm{~N} / \mathrm{A}$ & 0.50 \\
\hline 74 & Isophytol ? & 59.77 & 296 & $505-32-8$ & 0.47 \\
\hline 75 & Phytol type ? & 61.63 & 252 & $\mathrm{~N} / \mathrm{A}$ & 0.28 \\
\hline 76 & 3,7,11,15-Tetramethyl-1-hexadecanol & 63.14 & 298 & $645-72-7$ & 0.95 \\
\hline 77 & (2E ?)-3,7,11,15-Tetramethyl-2-hexadecen-1-ol (phytol) & 6368 & 296 & $150-86-7$ & 16.84 \\
\hline 78 & (2Z ?)-Phytol & 6449 & 296 & $150-86-7$ & 30.72 \\
\hline 79 & Unknown & 6521 & 296 & N/A & 0.64 \\
\hline 80 & Unknown & 6632 & 296 & N/A & 1.15 \\
\hline
\end{tabular}

\section{ACKNOWLEDGMENT}

The authors express their thanks to Mr. Thomas Steichen for helpful discussions regarding this study.

\section{REFERENCES}

1. Ishiwatari, M., K. Yamada, and R. Ishiwatari; Pyrolytic formation of $\mathrm{C}_{19}$ isoprenoid hydrocarbons from dihydrophytol: In relation to the genesis of pristane in petroleum; Chem. Lett 29 (2000) 206-207.

2. Bruan, V., M. Halim, M. Ziyad, C. Largeau, and A. Ambles: Characterization of the Moroccan Timahdit (X-layer) oil shale kerogen using pyrolysis and thermally assisted hydrolysis methylation; J. Anal. Appl. Pyrol. 61 (2001) 165-179.

3. Gonzales-Vila, F.J., P. Tinoco, G. Almendros, and F. Martin: Pyrolysis-GC-MS analysis of the formation and degradation stages of charred residues from lignocellulosic biomass; J. Agric. Food Chem. 49 (2001) 1128-1131.

4. Lichtfouse, E., C. Leblond, M. Da Silva, and F. Behar: Occurrence of biomarkers and straight-chain biopolymers in humin: Implications for the origin of soil organic matter; Naturwiss. 85 (1998) 497-501.

5. Dungait, J.A.J., N.A. Stair, B.E. van Dongen, R. Bol, and R.P. Evershed: Off-line pyrolysis and compoundspecific stable carbon isotope analysis of lignin moieties: A new method for determining the fate of lignin residues in soil; Rapid Commun. Mass Spectrom. 22 (2008) 1631-1639.

6. Moldoveanu, S.C.: Pyrolysis of organic molecules. Applications to health and environmental issues; Elsevier, Amsterdam, 2010.
7. Lam, J., B.O. Pedersen, and T. Thomasen: Pyrolytic disintegration of selected tobacco constituents and pyrosynthetic formation of aromatic hydrocarbons from cleavage products formed by pyrolysis; Beitr. Tabakforsch. Int. 13 (1985) 1-9.

8. Schlotzhauer, W.S. and I. Schmeltz: Pyrogenesis of aromatic hydrocarbons present in cigarette smoke II; Beitr. Tabakforsch. Int. 5 (1969) 5-8.

9. Pillsbury, H.C., C.C. Bright, K.J. O'Connor, and F.H. Irish: Tar and nicotine in cigarette smoke; J. Assoc. Off. Anal. Chem. 52 (1969) 458-462.

10. Moldoveanu, S.C., W.M. Coleman III, and J.M. Wilkins: Determination of polycyclic aromatic hydrocarbons in exhaled cigarette smoke; Beitr. Tabakforsch. Int. 23 (2008) 85-97.

\section{Corresponding author:}

Serban C. Moldoveanu

R.J. Reynolds Tobacco Co.

950 Reynolds Blvd.,

Winston-Salem, NC 27105

USA

E-mail:MoldovS@RJRT.com 
Table 16. Peak identification as a function of retention time for the pyrogram of chlorophyll a shown in Figure 6. $\mathrm{H}_{2}, \mathrm{H}_{2} \mathrm{O}, \mathrm{HCN}, \mathrm{CO}$, $\mathrm{NH}_{3}, \mathrm{CH}_{4}, \mathrm{~N}_{2}$, not included due to the MS settings.

\begin{tabular}{|c|c|c|c|c|c|}
\hline No. & Compound & Retention time $\min ^{a}$ & MW & CAS-No. & Mol \% \\
\hline 1 & Carbon dioxide & 4.98 & 44 & $124-38-9$ & 17.53 \\
\hline 2 & Propene & 5.26 & 42 & $115-07-1$ & 11.31 \\
\hline 3 & 2-Methylpropene & 5.91 & 56 & $115-11-7$ & 5.36 \\
\hline 4 & 1,3-butadiene & 6.15 & 54 & $106-99-0$ & 1.18 \\
\hline 5 & 3-Methyl-1-butene & 6.81 & 70 & $563-45-1$ & 0.87 \\
\hline 6 & 1-pentene & 7.54 & 70 & $109-67-1$ & 1.15 \\
\hline 7 & 2-Methyl-1-butene & 7.73 & 70 & $563-46-2$ & 1.10 \\
\hline 8 & 2-Methyl-1,3-butadiene (isoprene) & 8.47 & 68 & 78-79-5 & 3.04 \\
\hline 9 & 4-Methyl-1-pentene & 9.66 & 84 & $691-37-2$ & 1.93 \\
\hline 10 & 1-Methylcyclopentadiene & 15.35 & 80 & $96-39-9$ & 0.76 \\
\hline 11 & 4-Methyl-1-hexene & 15.65 & 98 & $3769-23-1$ & 1.06 \\
\hline 12 & Benzene & 18.27 & 78 & $71-43-2$ & 0.78 \\
\hline 13 & 2-Methylheptane & 21.43 & 114 & $592-27-8$ & 0.30 \\
\hline 14 & 6-Methyl-2-heptene & 22.38 & 112 & $73548-72-8$ & 0.70 \\
\hline 15 & 5-Methyl-2-heptene & 22.87 & 112 & $22487-87-2$ & 0.36 \\
\hline 16 & 2-Methyl-1-heptene & 23.30 & 112 & $15870-10-7$ & 0.93 \\
\hline 17 & Toluene & 24.75 & 92 & $108-88-3$ & 1.08 \\
\hline 18 & 2,6-Dimethyl-1-heptene & 26.61 & 126 & $3074-78-0$ & 2.01 \\
\hline 19 & 3,7-Dimethyl-1-octene & 29.30 & 140 & $4984-01-4$ & 0.64 \\
\hline 20 & 1,3-Dimethylbenzene & 29.87 & 106 & $108-38-3$ & 0.47 \\
\hline 21 & 3,6-Dimethyloctane & 30.06 & 142 & $15869-94-0$ & 0.28 \\
\hline 22 & 2,6-Dimethyl-1-octene & 31.42 & 140 & $6874-29-9$ & 0.21 \\
\hline 23 & 2,6-Dimethylnonane & 33.60 & 156 & $17302-28-2$ & 0.20 \\
\hline 24 & 4-Methyldecene & 33.68 & 154 & $13151-29-6$ & 1.77 \\
\hline 25 & 2,3-Dimethyl-1H-pyrrole & 36.14 & 95 & $600-28-2$ & 0.36 \\
\hline 26 & 2,3,7-Trimethyldecane & 37.47 & 184 & $62238-13-5$ & 0.18 \\
\hline 27 & 2,3,4-Trimethyl-1H-pyrrole & 38.72 & 109 & $3855-78-5$ & 0.54 \\
\hline 28 & 4-Ethyl-2-methyl-1H-pyrrole & 39.32 & 109 & $5690-96-0$ & 1.11 \\
\hline 29 & 2,6-Dimethylundecane & 40.14 & 184 & $17301-23-4$ & 0.89 \\
\hline 30 & 1-Cyclopropyloctane $?^{\mathrm{b}}$ & 40.25 & 154 & $1472-09-9$ & 0.31 \\
\hline 31 & 3,7-Dimethyl-1-undecene & 40.59 & 182 & $\mathrm{~N} / \mathrm{A}$ & 0.69 \\
\hline 32 & 2-Butyl-1,1,3-trimethylcyclohexane & 40.97 & 182 & $54676-39-0$ & 0.27 \\
\hline 33 & 3-Ethyl-2,4-dimethyl-1H-pyrrole & 41.06 & 123 & $517-22-6$ & 0.24 \\
\hline 34 & 4-Ethyl-2,3-dimethyl-1H-pyrrole & 41.22 & 123 & 491-18-9 & 0.73 \\
\hline 35 & 3-Ethyl-2,5-dimethyl-1H-pyrrole & 41.33 & 123 & $69687-78-1$ & 0.61 \\
\hline 36 & 7-Methyltridecane & 41.92 & 198 & $26730-14-3$ & 0.50 \\
\hline 37 & 4-Ethyl-2,5-dimethyl-1H-pyrrole & 42.02 & 123 & $\mathrm{~N} / \mathrm{A}$ & 0.90 \\
\hline 38 & 7-Methyl-6-tridecene & 42.94 & 196 & $24949-42-6$ & 1.88 \\
\hline 39 & 3-Ethyl-2,4,5-trimethyl-1H-pyrrole & 43.70 & 137 & $520-69-4$ & 0.88 \\
\hline 40 & 3,7,11-Trimethyl-1dodecene & 44.53 & 210 & $1189-38-2$ & 2.17 \\
\hline 41 & 2,6,10-Trimethyldodecane & 44.96 & 212 & $3891-98-3$ & 1.03 \\
\hline 42 & 2,6,10-Trimethyltridecane & 47.22 & 226 & $3891-99-4$ & 0.89 \\
\hline 43 & 4,8,12-Trimethyl-1-tridecene & 47.36 & 224 & $\mathrm{~N} / \mathrm{A}$ & 0.47 \\
\hline 44 & 2,3,5-Trimethyl-4-prop-2-enyl-1H-pyrrole & 49.38 & 149 & $\mathrm{~N} / \mathrm{A}$ & 0.45 \\
\hline 45 & $2,6,10-$ Trimethylpentadecane & 51.84 & 254 & $3892-00-0$ & 0.69 \\
\hline 46 & 2,6,10,14-Tetramethylpentadecane & 53.13 & 268 & $1921-70-6$ & 0.17 \\
\hline 47 & 2,6,10,14-Tetramethylpentadec-1-ene & 53.99 & 266 & $\mathrm{~N} / \mathrm{A}$ & 1.14 \\
\hline 48 & $2,6,10,14$-Tetramethylpentadec-1-ene (stereoisomer) & 54.13 & 266 & N/A & 0.40 \\
\hline 49 & 2,6,10,14-Tetramethylhexadec-2-ene & 55.18 & 280 & $56554-34-8$ & 0.68 \\
\hline 50 & $2,6,10,14$-Tetramethylpentadec-1-ene (stereoisomer) & 55.48 & 266 & $\mathrm{~N} / \mathrm{A}$ & 0.16 \\
\hline
\end{tabular}


Table 16 (cont.)

\begin{tabular}{ll|c|c|cc}
\hline No. & Compound & Retention time min $^{2}$ & MW & CAS-No. & Mol \% \\
\hline 51 & $7,11-15-T r i m e t h y l-h e p t a d e c a d i e n e$ & 56.09 & 278 & N/A & 0.92 \\
52 & {$[?-[?, ?-(?)]-3,7,11,15-T e t r a m e t h y l-2-h e x a d e c e n e$} & 280 & 280 & N/A & 2.29 \\
53 & [R-[R,R-( E)]]-3,7,11,15-Tetramethyl-2-hexadecene & 280 & 280 & $14237-73-1$ & 4.02 \\
54 & Neophytadiene & 278 & 278 & $504-96-1$ & 10.02 \\
55 & An eicosadiene & 278 & 278 & N/A & 0.87 \\
56 & (E)-2,4-Phytadiene & 278 & 278 & N/A & 2.42 \\
57 & Phytol & 296 & 296 & $150-86-7$ & 4.20 \\
58 & Heneicosene & 294 & 294 & N/A & 0.29 \\
59 & An eicosadiene & 278 & 278 & N/A & 0.87 \\
60 & A heneicosadiene & 292 & 292 & N/A & 0.17 \\
61 & A heneicosadiene & 292 & 292 & N/A & 0.15 \\
62 & A heneicosadiene & 292 & 292 & N/A & 0.16 \\
63 & Trimethyltridecylbenzene & 302 & 302 & N/A & 0.26 \\
\end{tabular}

a Small differences are seen in the retention time of identical compounds in phytol and chlorophyll pyrolyzate as a result of random variability in experimental conditions.

${ }^{\mathrm{b}} \mathrm{A}$ ? indicates a tentative/possible compound assignment 